\title{
STRATEGI PROGRAM KEMANDIRIAN UMMAT LAZISMU DALAM UPAYA PEMBERDAYAAN MASAYARAKAT DI KOTA PEKANBARU
}

\author{
Muharrani \\ STAI Diniyah Pekanbaru \\ Jl. Kuau No. 01 Sukajadi Pekanbaru \\ muharrani@diniyah.ac.id \\ Yeni Yasyah Sinaga \\ STAI Diniyah Pekanbaru \\ Jl. Kuau No. 01 Sukajadi Pekanbaru \\ yenisinaga51@yahoo.com \\ Lailan Rafiqah \\ STAI Diniyah Pekanbaru \\ Jl. Kuau No. 01 Sukajadi Pekanbaru \\ lailanrafiqah18@gmail.com
}

DOI: 10.46781/al-mutharahah.v17i2.163

\begin{abstract}
Community empowerment is absolutely necessary to create an independent society so that a good strategy is needed to be able to achieve it, LAZISMU is one of the institutions that strive to create an independent society in the economic sector through the community independence program, which is expected to be a problem solver for people who have difficulty in the economic sector through productive loans which in the end were able to deliver the mustahiks to become muzzaki. This study aims to determine how the LAZISMU community independence program strategy in the community empowerment efforts in the city of Pekanbaru. This research is qualitative narrative research. The research subjects were the director of the implementing agency, c.o in the fields of education and economics, and two mustahik or program beneficiaries. The results showed that the strategies implemented by LAZISMU in the community independence program were providing business capital assistance, providing productive facilities, providing business coaching and mentoring as well as providing entrepreneurial training and motivation. Meanwhile, our hope is that the results of this research can be used by institutions engaged in the same field, both government and private institutions so that in the end it can strengthen the people's economy.

Keywords: Program strategy, Independence, Community development.
\end{abstract}

Abstrak
Pemberdayaan masyarakat mutlak dilakukan untuk mewujudkan masyarakat yang mandiri
untuk itu perlu strategi yang baik agar mampu mencapainya, LAZISMU salah satu lembaga
yang berusaha mewujudkan masyarakat yang mandiri dalam bidang ekonomi melalui
program kemandirian ummat yang mana program ini diharapkan bisa menjadi problem solver
bagi masyarakat yang kesulitan dalam bidang ekonomi melalui pinjaman produktif yang pada
akhirnya mampu mengantarkan para mustahiknya menjadi muzzaki. Penelitian ini bertujuan
untuk mengetahui bagaimana strategi program kemandirian ummat LAZISMU dalam upaya
pemberdayaan masayarakat di kota Pekanbaru. Penelitian ini adalah penelitian naratif
kualitatif. Subyek penelitian adalah direktur badan pelaksana, c.o bidang pendidikan dan
ekonomi dan dua orang mustahik atau penerima manfaat program. Hasil penelitian 
menunjukkan bahwa strategi yang diterapkan oleh LAZISMU pada program kemandirian ummat yaitu memberikan bantuan modal usaha, memberikan bantuan sarana produktif, melakukan pembinaan dan pendampingan usaha serta memberikan pelatihan dan motivasi kewirausahaan. Sedangkan harapan kami dari hasil penelitian ini bisa dimanfaatkan oleh lembaga yang bergerak di bidang yang sama baik itu lembaga pemerintah maupun swasta sehingga pada akhirnya bisa memperkuat ekonomi masyarakat.

Kata Kunci: Strategi program; Kemandirian; Pemberdayaan masyarakat.

\section{A. PENDAhuluan}

Zakat merupakan salah satu rukun Islam yang diwajibkan bagi setiap muslim terhadap harta yang dimilikinya. Kita ketahui kewajiban dalam berzakat ini erat kaitannya dengan perekonomian masyarakat Islam, hal ini disebut dengan ma'aliyahijma'iyah. Berdasarkan prinsipnya zakat ini berpotensi sangat besar dalam pergerakan ekonomi masyarakat, namun zakat ini kurang banyak mendapat perhatian dibandingkan dengan kewajiban Sholat, berpuasa dan Haji ${ }^{1}$ Tujuan dari zakat ini adalah untuk menegakkan keadilan ekonomi dalam kehidupan masyarakat Muslim, sesuai Firman Allah dalam Surat Al Baqarah: 277 yang berbunyi:

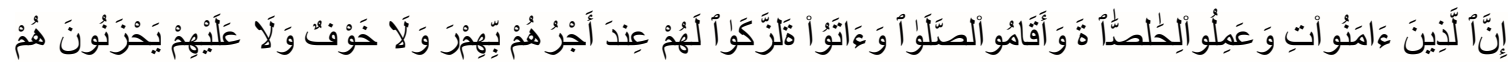

Artinya : "Sesungguhnya orang-orang yang beriman mengerjakan amal saleh, mendirikan sholat, dan menunaikan zakat, mereka mendapat pahala di sisi Tuhannya. Tidak ada kekhawatiran terhadap mereka dan tidak (pula) mereka bersedih hati" ${ }^{2}$

Secara strategis dilihat dari kacamata pandangan Islam bahwasannya zakat ini merupakan hal yang sangat penting dalam pembangunan kesejahteraan umat. Kita dapat membuktikannya lewat sejarah perkembangan Islam padfa masa kepemimpinan Rasulullah saw. Pada masa ini sumber keuangan negara yang sangat memiliki peran penting dalam pengembangan agama Islam baik itu dari dunia pendidikan, pengembangan infrastruktur, serta penyediaan segala layanan bantuan dalam kepentingan kesejahteraan sosial masyarakat Muslim salah satunya diperoleh dari dana zakat. Begitu juga sesuai dengan kondisi masyarakat miskin Indonesia zakat ini sangat berperan untuk mengatasi masalah tersebut lewat layanan bantuan, namun untuk meningkatkan kesejahteraan masyarakatnya masih mengalami kesulitan dalam memperoleh layanan bantuan tersebut.

Karena itulah penting diadakannya pengkajian secara maksimal terhadap pendistribusian zakat. Meskipun pada prinsipnya zakat untuk memenuhi kebutuhan pokok para mustahiq, namun tidak seharusnya dana zakat tersebut digunakan untuk hal-hal yang konsumtif saja. Harus ada upaya yang nantinya didistribusikan ke hal yang bersifat investasi untuk dijadikan modal bagi para mustahiq dan mengelola serta mengembangkan modal tersebut di dunia usaha yang nyata, harapannya status perekonomian mereka dapat berubah. ${ }^{3}$ Berdasarkan keterangan ini secara produktif pendayagunaan zakat ini benar-benar harus dikembangkan, proses memanfaatkan zakat produktif ini dilakukan untuk mengurangi kesenjangan sosial antara si kaya dan si miskin secra perlahan dengan memanfaatkan, sehingga para mustahiq dapat hidup mandiri, sehingga bisa menjadi muzzaki dikemudian hari.

LAZISMU merupakan Salah satu lembaga amil zakat tingkat nasional yang berkhidmat dalam pemberdayaan masyarakat. Yang mempunyai program kemandirian umat dalam program jangka panjang yang dapat menghantarkan dana ZIS menjadi pemecahan masalah dalam kehidupan masyarakat Muslim. Dana Zakat Infak dan sedekah ini diperoleh dari perseorangan, lembaga, dan Instansi lainnya yang akan dimanfaatkan dengan

\footnotetext{
${ }^{1}$ Saifuddin Zuhri, Zakat di Era Reformasi (Semarang: Fakultas Tarbiyah IAIN Walosongo, 2012), hlm 8.

${ }^{2}$ Departemen Agama RI, Al-Qur'an dan Terjemahnya. (Jakarta: Pustaka Amani. 2005), hlm 255.

${ }^{3}$ Ahmad Rofiq, Fiqh Kontekstual. (Semarang: Pustaka Pelajar Offseet, 2014), hlm 268.
} 
pendayagunaan ekonomi yang lebih produktif dan berkualitas. Penelitian ini memiliki tujuan untuk mengetahui bagaimana strategi program kemandirian ummat LAZISMU dalam upaya pemberdayaan msayarakat di kota Pekanbaru.

Lembaga amil zakat infaq shadaqah Muhammadiyah (LAZISMU) sebagai salah satu lembaga filantropi Islam yang melakukan pemberdayaan masyarakat telah mempunyai program jangka panjang salah satunya adalah program kemandirian ummat, yang mana program ini bertujuan untuk memberdayakan perekonomian masyarakat khususnya di kota Pekanbaru. Keberhasilan lembaga zakat ini akan tercapai jika bergantung pada beberapa komponen-komponen strategi dalam pelaksanaan kegiatan, seperti pada pengelolaan muzzaki, mustahiq, tenaga pelaksana serta sarana dan prasarana, komponen-komponen strategi ini merupakan kesatuan yang saling mendukung. Untuk itu lah strategi program harus betul dilakukan dengan serius sehingga bisa mecapai tujuan lembaga yang telah ditetapkan.

Strategi adalah suatu alat untuk menuju pencapaian jangka panjang. Strategi memiliki konsekuensi yang mempunyai banyak fungsi dan banyak dimensi serta penting untuk menjadi bahan pemikiran faktor-faktor baik itu internal maupun eksternal. ${ }^{4}$ Dalam kamus ilmiah populer, strategi dapat berarti Ilmu siasat perang, muslihat untuk mencapai sesuatu ${ }^{5}$

Strategi yang digunakan dalam penelitian ini adalah strategi program. Karena dari startegi program ini sangat mengutamakan dampak pada saat kegiatan itu dipernalkan dan dilakukan.strategi ini lebih mengutamkan manfaat dari kegiatan tersebut. Oleh sebab itu, strategi ini mecakup bagaimana sebuah organisasi memulai tahap pengenalan sebuah program kepada masyarakat dalam bentuk sosialisasi. Dengan demikian dari ketenaran organisasi ini masyarakat akan mengetahui dan menghenal lebih jauh sehingga mudah memahami dan berpoartisipasi dalam setiap kegiatan yang di programkan oleh organisasi tersebut.

Salah satu lembaga di Pekanbaru yang memiliki program pendistribusian dana ZISWAF adalah LAZISMU. Program kemandirian umat pada lembaga ini memang sangat menarik perhatian. Karena program ini mampu membekali dan memberikan ilmu pengetahuan serta keterampilan yang menimbulkan jiwa berwirausaha dalam meningkatkan kesejahteraan hidup serta menambah penghasilan. Strategi program kemandirian ini sangat tepat karena menunjukkan kepedulian Lembaga Amil Zakat, Infak dan Sedekah Muhammadiyah di Kota Pekanbaru kepada kondisi perekonomian mustahiq, juga membatu pemerintah dalam menanggulangi kemiskinan, serta mengurangi kesenjangan sosial dan meningkatkan kesejahteraan para mustahiq.

Salah satu aspek terpenting dalam kepribadian seorang individu adalah kemandirian. Seseorang yang hidup mandiri tidak lagi membutuhkan petunjuk yang detail secara terusmenerus bagaimana mencapai produk akhir, karena dia bisa memecahkan masalah dan bersandar pada diri sendiri. Kemandirian berkaitan dengan suatu kerja dan skill bagaimana melakukan sesuatu guna mencapai sesuatu yang lain dan bagaimana mengelola sesuatu. ${ }^{6}$ Kemandirian berarti terdapat kepercayaan terhadap ide dan diri sendiri yang berkenaan adanya kemauan dan kemampuan dalam menyelesaikan suatu hal sampai tuntas.

Berdasarkan pengertian dari para pakar di atas kita dapat menyimpulkan kemandirian ini sebagai usaha mempertahankan kelangsungan hidup dengan cara melepaskan diri baik itu dari orang tua atau orang-orang dewasa yang ada di sekelilingnya dalam hal mengerjakan sesuatu yang timbul dari dalam diri sendiri serta kepercayaan diri tanpa dipengaruhi dari lingkungan yaitu ketergantungan kepada orang lain, inisiatif dalam mengatur kebutuhan sendiri, serta mampu memecahkan segala permasalahan hidup tanpa dibantu orang lain. Kemampuan ini dapat dimiliki seseorang terhadap sesuatu yang akan dikerjakan atau

\footnotetext{
${ }^{4}$ Fred R David, Manajemen Strategi, Ed ke-10, (Jakarta: Salemba Empat. 2010), hlm 17.

${ }^{5}$ M. Dahlan Al Barry, Kamus Ilmiah Populer, (Surabaya: Arkola. 2005), hlm 448.

6 Parker, D.K. Menumbuhkan Kemandirian dan Harga Diri Anak. (Jakarta: Prestasi Pustakarya. 2005) hlm 226
} 
diputuskan baik dari sisi manfaat dan kerugian yang akan dialaminya. upaya yang dilakukan dalam nmeningkatkan harkat dan martabat masyarakat ini adalah lewat pemberdayaan yang nantinya akan mampu melepaskan diri dari keterbelakangan dan lingkaran kemiskinan. Artinya dalam memberdayakan ini masyarkat itu akan lebih mampu dan lebih mandiri, karena masyarakatlah yang menjadi aktor dan penentu pembangunan masa depan dan diberikan fasilitas untuk mengkaji dan mengatasi segala kebutuhan dan permasalahan kehidupan mereka serta menemukan solusi yang sangat tepat dalam mengakses sumberdaya yang akan dimiliki oleh mereka.

Penelitian ini bertujuan untuk mengetahui strategi program kemandirian umat di LAZISMU dalam upaya pemberdayaan masyarakat di kota Pekanbaru. Guna mendapatkan data yang lebih lengkap dan dapat memberi makna terhadap jawaban yang tepat dalam permasalahan yang diajukan, maka jenis penelitian yang digunakan adalah penelitian ini adalah naratif kualitatif. Untuk itu peneliti berhubungan langsung dengan data yang diselidiki yaitu tentang strategi dalam program kemandirian umat yang dilakukan LAZISMU dalam upaya pemberdayaan masyarakat di Kota Pekanbaru. Peneliti mengumpulkan data secara kualitatif dalam bentuk laporan dan uraian untuk mencari makna, dan dapat mengungkap data secara empiris dan sistematis di lapangan.

Jenis data tentang strategi program kemandirian ummat di LAZISMU, yang meliputi latar belakang, tujuan, prosedur (strategi), fasilitas yang digunakan dalam program kemandirian ummat, sumber data didapat dari direktur badan pelaksana, c.o bidang pendidikan dan ekonomi dan para penerima manfaat dari program tersebut (mustahik), pengambilan data dilakukan waktu program berlangsung.

\section{B. METODE PENELITIAN}

Data penelitian dikumpulkan melalui teknik wawancara, pengamatan dan dokumentasi. Adapun kegiatan wawancara dalam penelitian ini bertujuan untuk memperoleh informasi secara luas dan mendalam tentang strategi program kemandirian ummat di LAZISMU dalam upaya pemberdayaan masyarakat Kota Pekanbaru yang meliputi latar belakang, tujuan, prosedur (strategi), fasilitas yang dipergunakan. Wawancara dilakukan dengan Direktur badan pelaksana, c.o bidang pendidikan dan ekonomi dan para penerima manfaat dari program kemandirian ummat tersebut (mustahik). Kemudian pengamatan dilakukan dengan cara mengamati secara langsung mengenai proses pelaksanaan program kemandirian ummat di LAZISMU. Dan dokumentasi bertujuan untuk lebih memperkuat data penelitian ini, maka peneliti mengambil foto tentang kegiatan program kemandirian ummat di lapangan.

Selanjutnya data penelitian dikoreksi keabsahannya dengan menggunakan tehnik triangulasi, teknik pemeriksaan keabsahan data yang memanfaatkan sesuatu yang lain diluar data itu untuk keperluan pengecekan atau sebagai pembanding terhadap data itu, teknik triangulasi yang paling banyak digunakan ialah pemeriksaan melalui sumber lain. ${ }^{7}$ caranya dengan membandingkan data dari nara sumber kepada: Rivani Agustin selaku c.o bidang pendidikan dan ekonomi, Ali selaku penerima program (mustahik) dan Agung Pramurtyantyo selaku direktur badan pelaksana LAZISMU Pekanbaru.

Hasil wawancara dengan nara sumber yang telah peneliti rangkum untuk keperluan analisis yang digabungkan dengan hasil pengamatan dan hasil foto yang telah direkam dalam bentuk gambar, selanjutnya data yang telah didapat dari proses selanjutnya dapat disimpulkan menjadi data yang handal dan tidak menutup kemungkinan peneliti untuk meninjau kembali catatan-catatan yang didapat dari lapangan. Penelitian kualitatif menekankan pada analisis naratif yang sifatnya pemaknaan, Dalam pengumpulan data penelitian dilakukan melalui

\footnotetext{
${ }^{7}$ Moleong, Lexy J. Metode Penelitian Kualitatif. (Bandung: Remaja Rosdakarya. 2002) hlm 178
} 
empat kegiatan utama yaitu pengumpulan data, reduksi data, penyajian data serta pemberian makna.

\section{PEMBAHASAN}

Strategi merupakan suatu cara yang mutlak dilakukan guna mempermudah jalannya kegiatan pemberdayaan masayarakat sehingga hasilnya dapat memuaskan karena menurut strategi disusun untuk mencapai tujuan tertentu. ${ }^{8}$ Artinya terlebih dahulu dirumuskan tujuan yang jelas yang dapat diukur keberhasilannya. Ia tidak hanya berfungsi sebagai peta jalan yang harus ditempuh, tetapi juga berisi taktik operasionalnya, Adapun program yang dibentuk LAZISMU bertujuan untuk menjalankan program penggunaan zakat, infak dan sedekah dalam rangka pemberdayaan berupa usaha ekonomi. Adapun startegi yang dilakukan adalah:

1. Bantuan modal usaha

Memberikan bantuan usaha berupa uang dan barang sehingga mereka mampu memenuhi kebutuhan ekonomi keluarga dan tidak menjadi masyarakat yang meminta-minta bantuan. Sumber dana yang didapat oleh LAZISMU dari zakat infak dan sedekah. Bantuan modal usaha berupa pinjaman uang dan barang yang diberikan kepada warga binaan dan non binaandengan pengajuan harus ada rancangan anggaran belanja (RAB) tujuannya dengan adanya rancangan tersebut pihak LAZISMU mengetahui apa yang dibutuhkan oleh para mustahik sehingga uang atau barang yang diberikan bisa sesuai dengan apa yang dibutuhkan. Akan tetapi, ada syarat yang harus dipenuhi yaitu

a. Pertama harus produktif dari segi ekonomi, ada dua pendekatanyang digunakan untuk bantuan modal usaha produktif ini, yaitu pendekatan mudharabah dan qardul Hasan. Pendekatan mudharabah adalah bantuan modal yang diberikan kepada para pedagang kecil yang ada dipasar-pasar tradisional. Sedangkan qardul hasan adalah pinjaman tanpa bunga yang diberikan kepada para pedagang kecil yang ada disekitar kota Pekanbaru.

b. Kedua Track Record (Rekam Jejak) yaitu kandidat yang lebih senior dalam artian orang yang akan menerima bantuan ini minimal sudah pernah menjadi bagian dari LAZISMU misalnya pernah ikut kegiatan social dakwah yang diadakan oleh LAZISMU.

c. Ketiga Membentuk mindset, dalam artianpenerimaan bantuan yang diberikan kepada mustahik, selayaknya adalah benar-benar dapat menghidupi para mustahik dan selanjutnya dapat menumbuhkembangkan usaha mereka. Sehingga mereka ini nantinya bisa hidup sejahtera secara layak, tidak selamanya menjadi kaum penunggu pembagian zakat, infak dan sedekah.

d. Keempat mengerti tujuan program, yaitu mustahik juga harus mampu memperdayakan dana yang diberikan oleh LAZIZMU artiya dana yang telah diterima oleh mustahik harus dipergunakaan dengan baik dan benar yaitu untuk hal-hal yang lebih produktif melainkan bukan konsumtif secara terperinci.

e. Kelima terkhusus untuk warga non binaan yaitu bagi penerima yang ingin mengembangkan usaha juga diberikan bantuan dana apabila ingin mengembangkan suatu usaha dengan tujuan yang jelas. Adapun syaratnya harus ada sisi lain proses pemberdayaan juga dilakukan dengan perbaikan mentalitas dari awalnya sebagai mustahiq (penerima bantuan) menjadi seorang yang dermawan (muzakki). 


\section{Bantuan Sarana Produktif}

Pendistribusian sarana secara produktif yang diberikan dalam bentuk barang-barang produktif, digunakan untuk membantu fakir miskin dalam mengatasi permasalahan sosial dan ekonomi yang dihadapinya dimana dengan menggunakan barang-barang tersebut para mustahiq dapat membuka suatu usaha, bantuan yang disalurkan berupa mesin jahit, alat pertanian, gerobak jualan untuk pedagang, dan lain sebagainya.

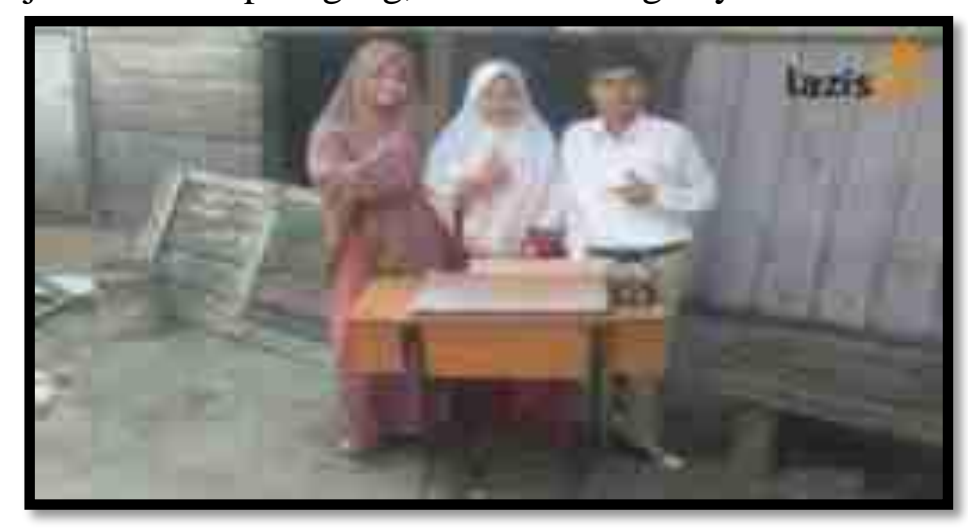

Gambar 1 : Pemberian bantuan sarana produktif (mesin jahit) kepada mustahik (Dokumentasi : 2019)

\section{Pembinaan dan Pendampingan Usaha}

Pemberian modal usaha disertai pembinaan agar ketika melakukan usahanya tidak menemui kesulitan dalam hal pendanaan dan bagaimana penggunaan dana yang telah diberikan sebagai modal usaha supaya sesuai dengen modal yang diberikan. Pembinaan dan pendampingan kepada masyarakat guna memberikan pejelasan tentang pendayagunaan bantuan modal usaha dan memberian suatu pemahaman bagaimana menjalankan usaha ekonomi dengan benar dan dapat mengeluarkan dari kemiskinan dan menjadi seorang muzakki serta dapat berkelanjutan dalam melakukan usaha yang ditekuninya. Pembinaan yang dilakukan dua kali dalam satu bulan yaitu pada pekan pertama dan pekan kedua. Sedangkan untuk jadwal pendampingan dilakukan satu bulan sekali

Pembinaan yang dilakukan bukan hanya pembinaan yang bersifat duniawi saja melainkan yang bersifat ukhrowi yang mana ini memberikan motivasi tersediri kepada para mustahik agar mampu menjadi mustahik yang memiliki kepribadian yang tangguh, bertanggung jawab dan mandiri sesuai syari'at Islam. Sedangkan pendampingan para mustahik yang dilakukan oleh LAZISMU Pekanbaru dengan melakukan pendampingan usaha bagi para mustahik yang bertujuan memberikan dorongan wawasan atau pengetahuan dan pendampingan untuk pengembangan usaha yang dilakukan oleh para penerima program (mustahik).

4. Pelatihan dan Motivasi Kewirausahaan

Kurangnya permodalan dalam usaha kecil yang dijalankan oleh orang miskin bukan menjadi patokan khusus sebagai kelemahannya, tetapi lebih menonjol pada sikap dan mental serta kurangnya kesiapan dalam memanajemen usahanya. Berdasarkan dari segi sisi ini dapat dilanjutkan pada tahan berikutnya setelah semua kebutuhan dasar mustahik sudah terpenuhi, adalah memberikan pendidikan dan pelatihan. Melalui pendidikan dan pelatihan ini para mustahik diberikan konsep-konsep kewirausahaan dengan segala macam seluk beluk permasalahan yang ada di dalamnya.Kegiatan ini sendiri diadakan dengan tujuan untuk memberikan wawasan dan juga motivasi untuk berwirausaha, tidak hanya pada yang sudah memulai tapi juga kepada yang baru akan memulai. Dalam berwirausaha harus berani, optimis, dan pantang menyerah apabila menemui kegagalan. 


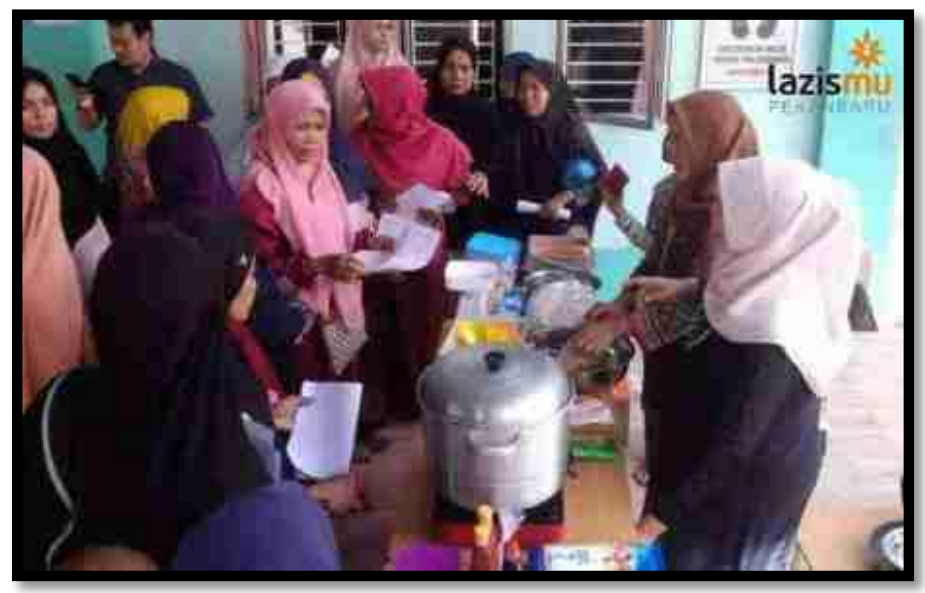

Gambar 2: Pelatihan penerima program kemandirian umat LAZISMU Pekanbaru (Dokumentasi: 2019)

Gambar suasana pelatihan pembuatan bakso dan nugget ikan patin yang dilakukan LAZISMU Pekanbaru di masjid Taqwa pasar Cik Puan Jl. Tuangku Tambusai dalam rangka meningkatkan keahlian dan kreativitas mustahik sehingga para mustahik dapat membuat usaha untuk meningkatkan ekonomi. Dalam gambar tersebut dapat kita lihat seorang pelatih menjelaskan dengan detail cara-cara membuat bakso dan nugget ikan dan para mustahik sangat antusias dalam mengikuti pelatihan tersebut.

Proses pemberdayaan ini lebih ditekankan pada proses pemberian atau pengalihan sebagian kekuasaan, kekuatan serta kemampuan masyarakat agar menjadi lebih berdaya dengan adanya penyediaan aset yang mendukung. Kecenderungan pertama ini disebut dengan kecenderungan primer. Kecenderungan yang kedua adalah apa yang diperkenalkan Paulo Freire sebagai konsientisasi (conscientization), yaitu proses pemahaman dan penumbuhan kesadaran terhadap situasi yang sedang terjadi, baik dalam kaitannya dengan relasi-relasi politik, ekonomi, dan sosial.

Masyarakat dikatakan berdaya apabila sudah dapat mandiri. Bukti bahwa masyarakat yang memperoleh manfaat dari program kemandirian umatini sudah dapat dikatakan mandiri dapat dilihat dari pengembalian dan pelunasan modal oleh para anggota dengan tepat waktu. Secara tidak langsung berindikasi bahwa usaha yang dijalankannya berkembang dan juga membentuk karakter disiplin dan tanggung jawab para anggota.Lebih lanjut bahwa kedepannya mereka mengajukan modal yang lebih tinggi lagi.Pemberdayaan dapat berhasil jika anggota mandiri secara teknis dan dapat menemukan solusi dari kendala usaha seperti pengelolaan, pemasaran, akses pasar sampai pada tahap daya saing di masyarakat dan memperoleh pengetahuan baru secara mandiri. Dan dapat meningkatkan potensi daerah serta memajukan perekonomian rumahtangganya.Lebih lanjut membawa perubahan sosial di masyarakat. 


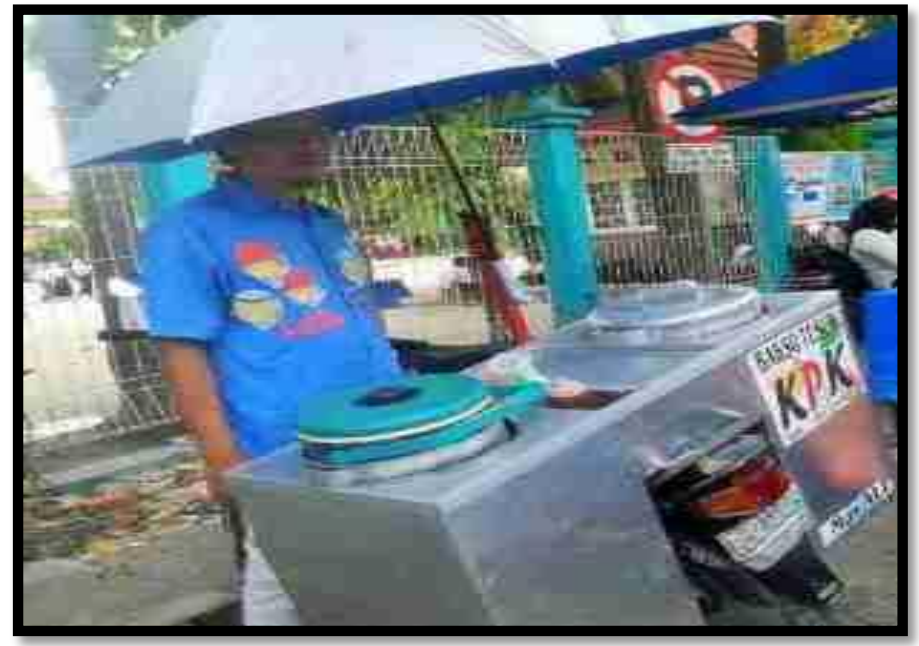

Gambar 3 : Salah satu mustahik yang sudah mandiri (pedagang bakso keliling 'KPK” pak Ali. Dokumentasi 2019)

Berdasarkan gambar diatas dapat dilihat Pak Ali (38 tahun) tampak sedang berjualan bakso di depan salah satu SD N di Kota Pekanbaru, beliau sudah bergabung menjadi mustahik di LAZISMU Pekanbaru sejak tahun 2014 dan sekarang pak Ali masih berjualan bakso keliling dengan penghasilan bersih sekitar Rp. 130.000/perhari sekarang beliau sudah mampu menghidupi keluarga dengan layak dan juga pak Ali sudah bisa ikut berqurban sejak tahun 2108-2019 di LAZISMU Pekanbaru. Jadi dari apa yang sudah dilakukan oleh pak Ali dapat diasumsikan bahwa pak Ali sang penjual bakso sudah mapan dan mandiri karena beliau bukan hanya mampu menghidupi keluarganya saja akan tetapi sudah mampu berbagi kepada sesama.

Pada program kemandirian umattarget yang ingin dicapai secara kualitatif yaitu masyarakat yang dibantu kemudian bisa menjadi bagian dari pelaku usaha yang mendatangkan perubahan sosial. Orang yang menerima manfaat itu menjadi bagian pemberdayaan yang optimal dan bisa merubah kondisi dari yang awalnya dibantu bisa membantu orang lain. Sehingga nanti semakin banyak orang yang menjalankan melakukan kegiatan bisnis ekonomi. Dengan dampak dari peran zakat itu yang menyantuni secara ekonomi, sosial ekonomi dan keagamaan, kemudian bisa menjadi teladan dan contoh bagi lingkungannya.Untuk secara kuantitatif tentunya semakin banyak yang bisa dibantu. Karena jika program ini banyak mempunyai manfaat di masyarakat.Sehingga hal tersebut bisa dikampanyekan dan dipublikasikan sebagai upaya-upaya penghimpunan Kemudian keberhasilan tersebut bisa menjadi sukses yang dapat menginspirasi baik secara kelembagaan maupun objek-objek yang dibina, sehingga dapat lebih berkembang dan menebarkan kebaikan serta manfaat untuk sesama.

Beberapa faktor pendukung dan faktor pengahambat yang dihadapi selama terselenggaranya program ini berdasarkan hasil observasi, wawancara oleh peneliti bersama para informan, penulis merangkumnya yaitu adanya kampanye yang didukung dengan potensi-potensi zakat yang berada di lembaga dan masyarakat Muhammadiyah, potensi sumber daya alam yang mendukung dapat dikembangkannya suatu kegiatan ekonomi, adanya prospek pasar yang sesuai dengan wilayah pembangunan usaha dan adanya sumber daya manusia atau pemuda di wilayah yang dapat diberdayakan

Sedangkan faktor penghambat yaitu minimnya kesadaran para penerima modal usaha dalam meningkatkan produktifitasnya dan mengikuti prosedur yang ada baik dari pengembalian modal, tidak sesuainya harapan dan instruksi yang diberikan oleh Lembaga LAZISMU. Kita melihat Mental masyarakat dari pemuda sampai kategori dewasa memiliki mental yang sangat minim dalam berwirausaha dan budaya atau culture masyarakat yang anti perubahan karena tidak berani keluar dari zona nyaman, tidak mau berkembang berjuang dan 
berjiwa pekerja serta adanya lembaga maupun masyarakat yang kontra produktif dan tidak peduli akan konteks pemberdayaan yang sesungguhnya terhadap UMKM seperti rentenir dan lembaga keuangan.

\section{SIMPULAN}

Berdasarkan dari hasil wawancara, pengamatan, dan dokumentasi maka dapat disimpulkan bahwa strategi pelaksanaan program kemandirian ummat yang ada di LAZISMU dilakukan dengan cara memberikan bantuan modal usaha, memberikan bantuan sarana produktif, melakukan pembinaan dan pendampingan usaha serta memberikan pelatihan dan motivasi kewirausahaan.

Akan tetapi catatan pentingnya adalah keberhasilan suatu strategi pemberdayaan zakat berkaitan dengan kapasitas pengelola (amil) pada lembaga bersangkutan termasuk pada pilihan antara produk zakat yang konsumtif atau zakat yang produktif. Namun keterbatasan modal yang dialami oleh para mustahik juga perlu diperhatikan. Perkembangan usaha yang dilakukan oleh mustahik dapat menjadi tolak ukur seberapa besar keberhasilan strategi yang dilakukan LAZISMU dalam mengatasi pemberdayaan perekonomian mustahik.

\section{DAFTAR PUSTAKA}

Rofiq, Ahmad, Fiqh Kontekstual. Semarang: Pustaka Pelajar Offseet, 2004. Departemen Agama RI, Al-Qur'an dan Terjemahnya. Bandung: Diponogoro, 2010. Fred, R David Manajemen Strategi, Ed ke-10. Jakarta: Salemba Empat, 2006. M. Dahlan Al Barry, Kamus Ilmiah Populer, Surabaya: Arkola, 2005.

Moch Ali Aziz. Ilmu Dakwah, Jakarta: Kencana, 2009

Moleong, Lexy J. Metode Penelitian Kualitatif. Bandung: Remaja Rosdakarya, 2002

Parker, D.K. MenumbuhkanKemandirian dan Harga Diri Anak. Jakarta: Preasi Pustaka, 2005 Syaifuddin Zuhri. Zakat di Era Reformasi. Semarang: Fakultas Tarbiyah IAIN Walisongo, 2012 